\title{
Phytoplankton assemblages and characterization of a Dinophysis acuminata population during an upwelling-downwelling cycle
}

\author{
Sonsoles González-Gil ${ }^{1,3, *, * *}$, Lourdes Velo-Suárez ${ }^{1, * *}$, Patrick Gentien$^{2}$, \\ Isabel Ramilo ${ }^{1}$, Beatriz Reguera ${ }^{1}$ \\ ${ }^{1}$ Instituto Español de Oceanografía, Centro Oceanográfico de Vigo, Aptdo. 1552, 36200 Vigo, Spain \\ ${ }^{2}$ IFREMER, Centre de Brest, DYNECO, Pointe du Diable BP70, 29280 Plouzané, France \\ ${ }^{3}$ Present address: Instituto Español de Oceanografía, Orense 58, $7^{\mathrm{a}}$ planta, 28020 Madrid, Spain
}

\begin{abstract}
The distributions of Dinophysis acuminata, its potential prey Myrionecta rubra, and the microplankton populations associated with them, were studied in Ría de Pontevedra (NW Spain) during a 2 wk cruise that covered an upwelling-downwelling cycle, and during intensive sampling over $21 \mathrm{~h}$ at the end of the cruise. Special attention was focused on the characterization and physiological condition of $D$. acuminata. There was vertical segregation between a phytoplankton assemblage that was dominated by upwelling-promoted diatoms and another assemblage that was dominated by small dinoflagellates located in the warmer surface layer $(0$ to $5 \mathrm{~m})$ where $D$. acuminata was observed. High spatio-temporal variability was observed in the frequency of cells containing starch granules (indicating photosynthetic activity) and digestive vacuoles (indicating heterotrophic feeding); this pattern corresponded with the apparent availability of $M$. rubra cells. Populations of $D$. acuminata and $M$. rubra have their own niches and distinct responses to physical forcing, but both are located in common water masses and occasionally meet. Changes in vacuolation of $D$. acuminata were followed by a substantial increase $(\sim 35 \%)$ in cellular volume. D. acuminata did not exhibit daily migratory behaviour, and expressed a high division rate $\left(0.51 \mathrm{~d}^{-1}\right)$ under downwelling conditions. This work sheds new light on the relation between $D$. acuminata populations and its potential prey, and on its ecophysiology; it also questions previous assumptions about the environment that is suitable for its development.
\end{abstract}

KEY WORDS: Harmful algal blooms $\cdot$ Plankton communities $\cdot$ Dinophysis acuminata $\cdot$ Myrionecta rubra $\cdot$ Predator-prey interactions

\section{INTRODUCTION}

The Galician Rías Baixas are 4 tectonic valleys on the NW coast of Spain, where seasonal upwelling acts as the driving force controlling phytoplankton dominance (Figueiras et al. 1994, Tilstone et al. 1994). From spring to early autumn (March to October), the predominance of northerly winds promotes upwelling of nutrient-rich Eastern North Atlantic Central Water (ENACW) (Wooster et al. 1976, Álvarez-Salgado et al. 2003). The combination of moderate upwelling and thermohaline stratification has been identified as an optimum scenario for the development of harmful algal blooms (Tilstone et al. 1994), especially those of Dinophysis spp. (Reguera et al. 1995); dominance of dinoflagellates is reached during relaxation and downwelling in upwelling-downwelling cycles common to all regions subject to seasonal upwelling (Pitcher et al. 2005).

In autumn and winter (October to March), southerly winds are predominant in Western Iberia. The transition from the end of the upwelling season, with strong downwelling pulses and massive advection of shelf 
waters into the Rías, to winter conditions, creates another favourable scenario for bloom development, and the most intense toxic microalgae events take place at this time of the year (Fraga et al. 1988, Figueiras et al. 1994, Sordo et al. 2001, Pizarro et al. 2008).

Dinophysis acuminata and D. acuta are the most noxious Dinophysis species in the Galician Rías Baixas and in other locations in European Atlantic coastal waters (Reguera \& Pizarro 2008). Both species are lipophilic toxin (okadaic acid and its derivatives, pectenotoxins) producers, and cause prolonged shellfish harvesting closures at low to moderate cell densi-

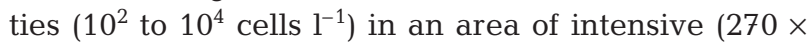
$10^{3} \mathrm{t} \mathrm{yr}^{-1}$ ) raft-mussel cultivation (Franco 2006). In contrast with $D$. acuta, which is a very seasonal species in Western Iberia, populations of D. acuminata are extremely persistent, and can be observed under wide ranges of salinity (from 30 to 35.5 ) and temperature (from 13 to $22^{\circ} \mathrm{C}$ ). This species can exhibit an alternation of peaks and troughs throughout the whole upwelling season, and a final major peak during autumn downwelling events (Reguera et al. 1993, Escalera et al. 2006). Understanding the strategies by which $D$. acuminata maintains itself in the plankton community during such long periods is a challenge to phytoplankton ecologists.

Observation of food vacuoles containing remains of ciliates in phototrophic species of Dinophysis confirmed their mixotrophic nature (Jacobson \& Andersen 1994), and explained difficulties met with in establishing cultures. Recently, Park et al. (2006) identified the ciliate prey Myrionecta rubra (=Mesodinium rubrum), which when itself fed on a crytophyte (Teleaulax sp.), allowed the establishment of laboratory cultures of Dinophysis with very high division rates ( $>1$ doubling $\left.\mathrm{d}^{-1}\right)$. Nevertheless, the frequency of cells containing food vacuoles in natural populations of $D$. acuminata and $D$. norvegica is very variable in NE US coastal waters and in the Baltic Sea (Jacobson \& Andersen 1994, Carvalho et al. 2008), and undetectable during late stages of $D$. acuta blooms in the Galician Rías Baixas (Pizarro et al. 2008).

Diel morphological and biochemical changes associated with nitrate reduction (Fritz et al. 1996), photosystem activity (Samuelsson et al. 1983) and toxin production (Lawrence \& Cembella 1999) have been reported in marine dinoflagellates (Seo \& Fritz 2002). Production of starch, which is the main reserve compound in plants, is related to photoautotrophy in eukaryotes (Seo \& Fritz 2002). Therefore, in mixotrophic species such as Dinophysis spp., observation of starch granules in lugol-stained samples can be used as an indicator of phosynthetic activity.

Diel vertical migration (DVM) throughout the water column enables dinoflagellates to reach nutrient-rich deeper waters at night and return to well illuminated layers during the day; nevertheless, a single species may be able to switch from migratory to layer-forming behaviour during different nutritional modes (especially in mixotrophs) and/or stages of population growth (reviewed by Cullen \& McIntyre 1998). Several species of Dinophysis migrate vertically, but different species of the genus, or even the same species in different locations, have been reported to remain in the pycnocline or in the surface layer (reviewed by Maestrini 1998). Villarino et al. (1995) reported that $D$. acuminata showed marked DVM in Ría de Vigo, its maxima being at $10 \mathrm{~m}$ at night and in the top $3 \mathrm{~m}$ at midday. The same migration pattern was exhibited by 2 co-occurring red-tide forming dinoflagellates (Ceratium furca and Scrippsiella trochoidea) and by Myrionecta rubra (the potential prey of $D$. acuminata). Similar migration of the cell maxima between $10 \mathrm{~m}$ at night and the top $5 \mathrm{~m}$ in the morning was observed in the same species from Ría de Pontevedra (Reguera et al. 2003), and between 15 and $5 \mathrm{~m}$ in $D$. acuta from New Zealand (MacKenzie 1992). Nevertheless, D. acuta cells remained aggregated in the top $6 \mathrm{~m}$ during the last stages of a bloom in Ría de Pontevedra (Pizarro et al. 2008), and dense populations of $D$. norvegica seem to remain in the pycnocline in the Baltic Sea (Carpenter et al. 1995).

During May to June 2005, a 2 wk multidisciplinary cruise was carried out in Ría de Pontevedra with advanced instrumentation that allowed high resolution vertical sampling of physical and biological properties of the water column during an upwelling-downwelling cycle. Descriptions of the formation of thin layers dominated by Pseudo-nitzschia spp., the fate of Dinophysis acuminata, and of physical and biological interactions during this upwelling-downwelling cycle are given in an earlier publication (Velo-Suárez et al. 2008). Here, we focus on the phytoplankton assemblages and on the characterization of $D$. acuminata populations and their relation with their potential ciliate prey Myrionecta rubra.

\section{MATERIALS AND METHODS}

Sampling overview. Sampling was carried out in Ría de Pontevedra (Galicia, NW Spain) at 2 spatio-temporal scales: (1) daily sampling (from 06:00 to 16:00 h GMT) on a grid of stations (Fig. 1; Table 1) during a 2 wk (30 May to 14 June 2005) multidisciplinary cruise (HABIT 2005), and (2) $21 \mathrm{~h}$ of intensive (every 1 to $2 \mathrm{~h}$ ) sampling on 13-14 June at a fixed station (Stn 6 in Fig. 1) in the same Ría. The IFREMER (Institut Francais de Recherche pour l'Exploitation de la Mer) high-resolution particle size/CTD/ video analyzer (IPSAP) was 


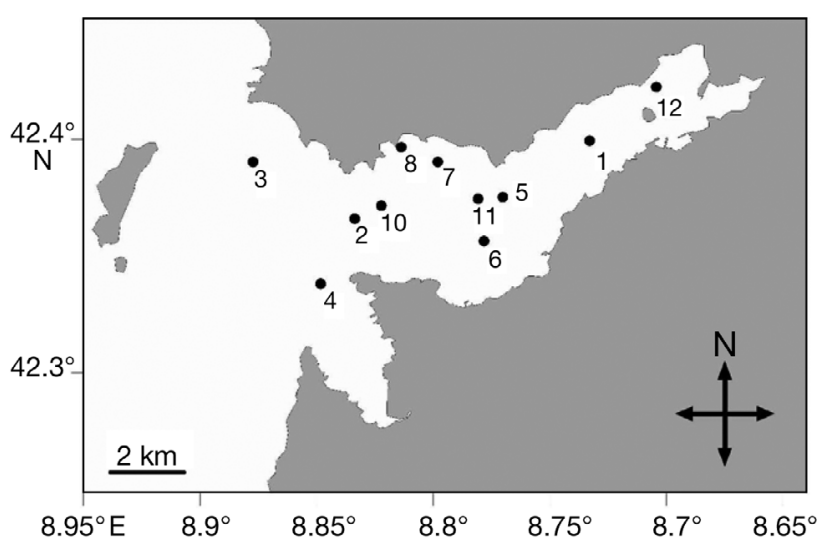

Fig. 1. Map of Ría de Pontevedra (NW Spain) showing stations sampled during the survey

Table 1. Number of samples in each sampling station during the cruise

\begin{tabular}{|cc|cc|}
\hline Station & No. of samples & Station & No. of samples \\
\cline { 1 - 2 } 1 & 43 & 7 & 4 \\
2 & 48 & 8 & 4 \\
3 & 48 & 10 & 6 \\
4 & 20 & 11 & 4 \\
5 & 36 & 12 & 6 \\
6 & 11 & & \\
\hline
\end{tabular}

used to obtain fine-scale vertical distributions of physical and biological parameters (depth, temperature, salinity, photosynthetically active radiation (PAR) and in vivo fluorescence) and suspended particles in the water column (see details in Gentien et al. 1995, VeloSuárez et al. 2008). This profiler is able to collect samples from specific depths, where structures of interest (chlorophyll maxima, pycnoclines, maximum particle loads) may be detected. Samples are collected by means of a peristaltic pump (on deck) that is connected to the profiler with a $45 \mathrm{~m}$ hose; samples from each depth can be collected either directly from the profiler (unconcentrated natural samples), or the water flow can be filtered through a set of superimposed framed meshes (150-70-20 $\mu \mathrm{m})$ to obtain size-fractionated concentrates. The meshes are placed on top of a container that keeps the plankton fractions suspended in freeflowing seawater, and allows their recovery with the least possible damage to the cells.

Vertical net hauls $(20 \mu \mathrm{m}$ mesh) and size-fractionated (20 to $70 \mu \mathrm{m}$ ) concentrates from specific depths (profiler) were collected to obtain quick quasi real-time qualitative information on live phytoplankton. These samples were immediately examined on board under a microscope (Zeiss AXIOVERT 135; 100×, 400×) with epifluorescence, and were used to select the stations and depths on which to focus additional sampling.
Plankton sample aliquots that were preserved with different fixatives were collected according to the objectives pursued: (1) unconcentrated natural samples fixed with acidic Lugol's solution for quantification of the phytoplankton community and of the ciliate Myrionecta rubra; (2) $500 \mathrm{ml}$ to 11 seawater samples concentrated through $20 \mu \mathrm{m}$ filters to a final volume of $50 \mathrm{ml}$, and fixed with Lugol's for quantification of Dinophysis spp. and of the frequency of starch containing cells; and (3) size fractionated (20 to $70 \mu \mathrm{m})$ concentrates fixed with buffered formaldehyde $(4 \%)$ to estimate frequencies of cells containing food vacuoles, and to recognize dividing and recently divided cells of Dinophysis spp. The intensive $21 \mathrm{~h}$ sampling was carried out at a fixed station on 13-14 June (Fig. 1, Stn 6). Samples (2 l) were collected at 0, 2, 4, 6, 8, 10, 12, 15, 18 and $20 \mathrm{~m}$ depth using a hose that was coupled to the CTD, every $2 \mathrm{~h}$ from 17:00 to 04:30 $\mathrm{h}$, and every hour from $04: 30$ to $08: 30 \mathrm{~h}$, which is the time window in which $D$. acuminata division occurs in this region (Reguera et al. 2003).

Phytoplankton counts and analyses. Phytoplankton and Myrionecta rubra counts were carried out under an inverted microscope (Nikon ECLIPSE 2000) following the Utermöhl (1931) method. The volume of the sedimentation columns (10 to $25 \mathrm{ml}$ ) was chosen depending on the plankton biomass (columns of $10 \mathrm{ml}$ were used when chl $a$ values were $>15 \mu \mathrm{g} \mathrm{l}^{-1}$ ) to prevent the overlay of phytoplankton cells at the bottom of the chamber. Phytoplankton abundance was determined to species level when possible. Two transects were examined at $400 \times$ magnification to include the smaller and more abundant species, while the whole bottom of the chamber was examined at $100 \times$ to enumerate larger species. To count Dinophysis spp., 3 to $10 \mathrm{ml}$ aliquots of the concentrated sam-

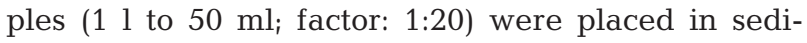
mentation chambers, and the whole surface of the chamber was scanned at $100 \times$, so that the detection

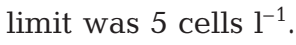

Principal components analysis (PCA) was used to reduce and simplify the information included in the list of species abundance, resolve changes in species composition, and identify assemblages within the plankton community between 31 May and 10 June. The analysis was carried out, with the correlation matrix of species abundances being transformed to $\log (X+1)$, where $X$ is the number of cells per litre. Since double 0 values in the correlation matrix can distort the results, these were reduced by including in the analysis only those species that were present in at least $30 \%$ of the samples. This provided an initial matrix of 108 species (see Table 1 for cases). A separate analysis was carried out with the data from the intensive sampling (13-14 June) where only dinoflagellates and Myrionecta rubra (the 
overwhelming components of the microplankton community during downwelling) were identified and counted. In this case, an initial matrix of 29 species (species that were present in at least $10 \%$ of the samples) and 112 cases were obtained.

Division rates. In situ division rates of Dinophysis acuminata were estimated from the frequency of dividing (paired) and recently divided (incomplete development of the left sulcal list) cells, which were recognized by their distinct morphology as described by Reguera et al. (2003). In situ division rates were estimated in samples corresponding to the Dinophysis maxima during the intensive sampling (13-14 June) at Stn 6 following the model of Carpenter \& Chang (1988):

$$
\mu=\frac{1}{n\left(T_{\mathrm{c}}+T_{\mathrm{r}}\right)} \sum_{i=1}^{n}\left(t_{\mathrm{s}}\right)_{i} \ln \left[1+f_{\mathrm{c}}\left(t_{i}\right)+f_{\mathrm{r}}\left(t_{i}\right)\right]
$$

where $\mu$ is the daily average specific division rate, $f_{c}$ is the frequency of cells in the cytokinetic (or paired cells) phase (c) and $f_{\mathrm{r}}$ is the half frequency of cells in the recently divided (incomplete development of the left sulcal list) (r) phase in the $i^{\text {th }}$ sample. $T_{\mathrm{C}}$ and $T_{\mathrm{r}}$ are the duration of the $\mathrm{c}$ and $\mathrm{r}$ phases, which are considered as 'terminal events' (sensu Carpenter \& Chang 1988) in this work; $n$ is the number of samples taken in a $24 \mathrm{~h}$ cycle, and $t_{\mathrm{s}}$ is the sampling interval in hours. The duration of the selected terminal events, $T_{\mathrm{C}}+T_{\mathrm{r}}$, was estimated as the time interval necessary for a cohort of cells to pass from one phase to the next; in this case, the time interval between the time $t_{0}$, when the frequency of cells undergoing cytokinesis is maximum $\left(f_{\mathrm{c}}=T_{\mathrm{c}}\right)$, and the time $t_{1}$, when the fraction of recently divided cells is maximum $\left(f_{\mathrm{r}}=\right.$ $T_{\mathrm{r}}$ ), was calculated as:

$$
\frac{1}{2}\left(T_{\mathrm{c}}+T_{\mathrm{r}}\right)=\left(t_{0}-t_{1}\right)
$$

where $T_{\mathrm{C}}, T_{\mathrm{r}}, t_{0}$ and $t_{1}$ were calculated after fitting a 7 th degree Gaussian ( $<$ 0.05) function to the frequency data.

Characterization of Dinophysis acuminata populations. The frequency of cells containing digestive vacuoles (formalin-fixed concentrates) was used as an indication of recent phagotrophic feeding, and the frequency of cells with starch deposits (Lugol's-fixed concentrates) as an indication of photosynthetic activity. These frequencies were estimated daily in samples from 2 stations (Fig. 1, Stns 1 and 3) at the depth of the Dinophysis acuminata maximum and in the whole water column when Dinophysis was abundant. A minimum of 100 specimens sample ${ }^{-1}$ were scanned.

Measurements of the cells and their intracellular starch granules and food vacuoles were obtained using the image analyzer Image Pro Plus 4.0 Program (Media Cybernetics). A minimum of 50 starch granules and 50 vacuoles from different specimens were measured. Maximum length $(L)$ and dorso-ventral depth $(W)$ of Lugol's-fixed Dinophysis acuminata cells were measured in at least 60 micrographs to estimate mean size at the beginning and end of the sampling period at both stations. Their equivalent biovolume was estimated as described by Olenina et al. (2006). Autofluorescence of live samples and Dinophysis specimens was observed on board under the inverted microscope with a blue filter set (excitation 450 to $490 \mathrm{~nm}$, emission $520 \mathrm{~nm}$ long pass). Occasionally, SYBR-Green I fluorochrome (Molecular Probes) was used at a concentration of $1 / 10000$ of the stock solution (Marie et al. 2005) as a nucleus acid stain. All micrographs were taken with a Nikon D70 camera that was coupled to the microscope.


Fig. 2. Phase-contrast micrographs of microplankton communities from concentrated samples collected at specific depths with the profiler and pump system: (A) dominated by centric diatoms and a few scattered Dinophysis acuminata cells during upwelling, and (B) a concentrate collected at $3 \mathrm{~m}$ during downwelling, dominated by $D$. acuminata (note the abundance of cells that are full of digestive vacuoles). Scale bar $=100 \mu \mathrm{m}$ in both frames 


\section{RESULTS}

\section{Microplankton assemblages}

Vertical profiles of physical properties obtained with the profiler and acoustic Doppler current profiler (ADCP) records indicated an upwelling event during the first days of the cruise (30 May to 1 June), a brief period of relaxation (2-3 June), a new upwelling pulse (4-9 June), and finally downwelling (10-13 June) with vertical displacement of the chlorophyll maximum and selection of swimming dinoflagellates near the surface (see Velo-Suárez et al. 2008).

Diatoms - mainly Chaetoceros spp. (C. curvisetus, C. didymus, and C. socialis), Leptocylindrus danicus, Guinardia delicatula, and Pseudo-nitzschia spp.were numerically dominant throughout the water column, while C. socialis and Pseudo-nitzschia spp. (up to $1.5 \times 10^{6}$ cells $^{-1}$ ) were the dominant species within the thin layer. Chaetoceros spp. together with Pseudonitzschia spp. comprised $>70 \%$ of the diatom population at all depths in all stations sampled during upwelling and relaxation conditions. By the end of the survey (13-14 June intensive sampling), dinoflagellates became dominant and diatoms were displaced downwards. This downwelling phytoplankton community was dominated by Dinophysis acuminata, Prorocentrum micans, Ceratium spp., Protoperidinium spp. and Gymnodinium spp. (Fig. 2).

Two selected profiles of phytoplankton composition and concentration at Stn 3 during upwelling and relaxation conditions are shown in Fig. 3. Dinophysis acuminata maxima (up to $7 \times 10^{3}$ cells $^{-1}$ ) were never associated with the subsurface chlorophyll maximum (SCM) in the pycnocline region that was in contact with the nutrient-rich upwelled waters, but was instead in upper warmer waters (Fig. 3A). The relaxation event was very brief and did not cause significant changes in community composition, but increased the thickness of the SCM.

Two principal components (PC) that explained $32.8 \%$ of the total variance in the original data set of microplankton abundance during upwelling, relaxation and the beginning of downwelling (30 May to 10 June) were extracted by the PCA. The first principal component (PC1) explained 21.4\%, while the second (PC2) explained $11.5 \%$ of the total variance. Large pennate diatoms (Pleu- rosigma-like spp.) were the only group that showed a small negative load with PC1 (Table 2).

The load arrangement of PC1 (with almost all groups having positive values) and the positive correlation of the scores of this component with the logarithm of total cell abundance $(r=0.9)$, suggest that this component explained the variance due to variations in cell concentration. Consequently, high PC1 scores marked the most abundant species during the cruise. The dinoflagellates Scrippsiella spp., Prorocentrum micans and Dinophysis acuminata showed the highest positive loads (>0.5) with PC2, while the diatoms Stephanopyxsis turris, Eucampia zodiacus and Guinardia striata together with the silicoflagellate Distephanus speculum had the highest negative loads $(<-0.5)$ (Table 2). Myrionecta rubra and cryptophycean flagellates had moderate and very similar positive loads (0.26 and 0.32) with PC2. This factor differentiated an assemblage (positive loads) that was composed of the most abundant dinoflagellate groups located near the surface (PC2 was positively correlated with the logarithm of the total dinoflagellate abundance; $r=0.4$ ) and

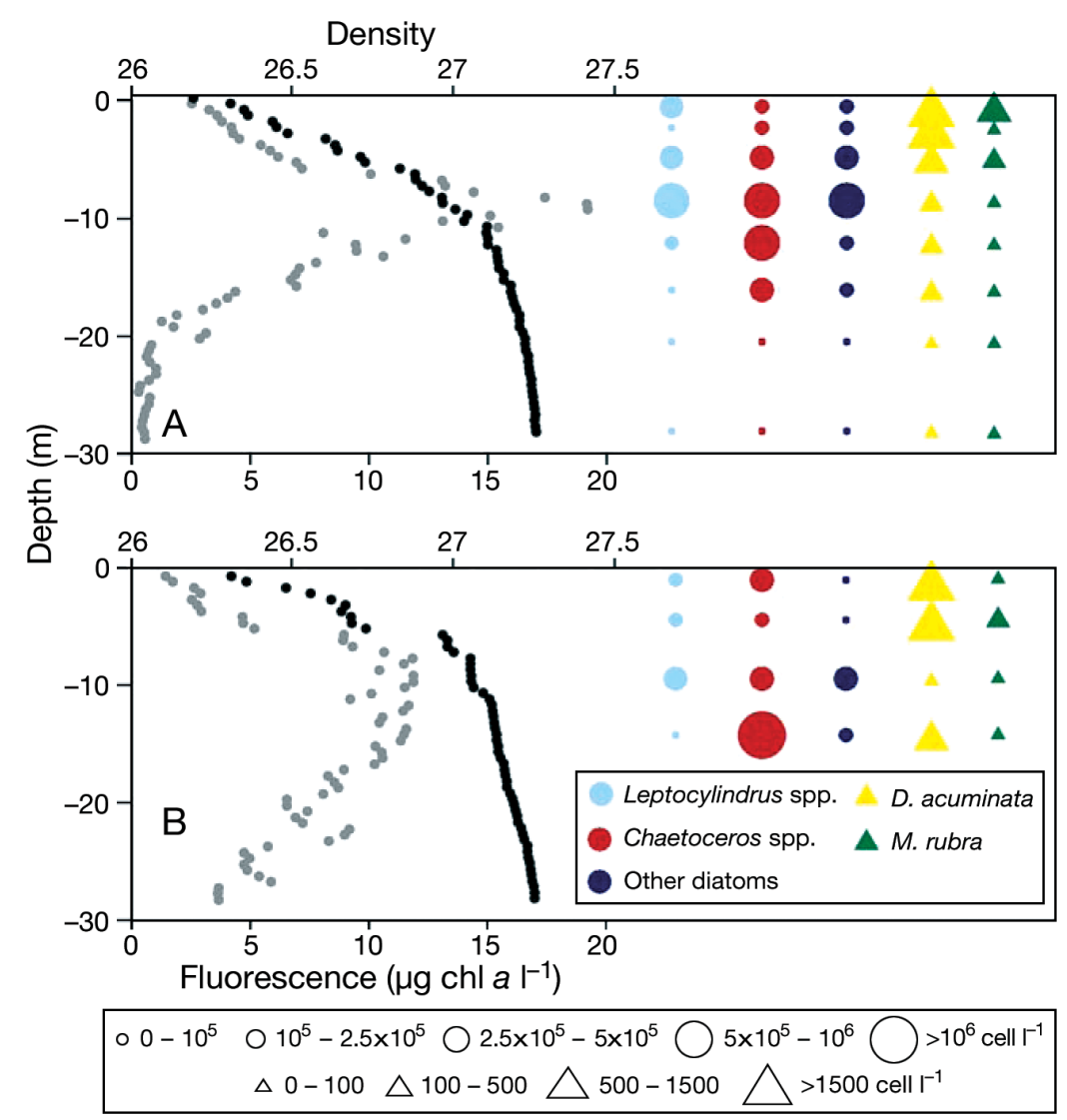

Fig. 3. Vertical distribution of density $\left(\sigma_{\mathrm{t}}, \bullet\right)$, in vivo fluorescence $\left(\bullet, \mu \mathrm{g} \mathrm{chl} \mathrm{a}{ }^{-1}\right)$ and, relevant diatom species/groups, Dinophysis acuminata and its potential prey Myrionecta rubra at Stn 3. (A) Upwelling conditions, (B) relaxation between upwelling pulses. Note the different scales of abundance for D. acuminata and M. rubra 
Table 2. Correlation coefficients of species and taxa selected for principal component analysis (PCA) with the 2 principal components for the whole cruise (31 May to 13 June 2005). Species and taxa are ordered according to PC1. The highest positive loads for PC2 are in bold; the highest negative loads are in bold italic. Target taxa in this study are also in bold text

\begin{tabular}{|c|c|c|c|}
\hline Group & Taxon & PC1 & $\mathrm{PC} 2$ \\
\hline Diatoms & Large pennate (Pleurosigma-like) & -0.04 & -0.12 \\
\hline Dinoflagellates & Dinophysis rotundata & 0.08 & -0.04 \\
\hline Diatoms & Licmophora spp. & 0.11 & 0.40 \\
\hline Dinoflagellates & Protoperidinium cf. conicum & 0.14 & 0.36 \\
\hline Diatoms & Chaetoceros didymus & 0.14 & -0.19 \\
\hline Dinoflagellates & Torodinium spp. & 0.17 & 0.31 \\
\hline Dinoflagellates & Scrippsiella spp. & 0.19 & 0.67 \\
\hline Ciliates & Myrionecta rubra & 0.20 & 0.26 \\
\hline Dinoflagellates & Protoperidinium bipes & 0.22 & 0.12 \\
\hline Dinoflagellates & Prorocentrum micans & 0.30 & 0.55 \\
\hline Dinoflagellates & Diplopsalis lenticula & 0.32 & 0.28 \\
\hline Diatoms & Guinardia flaccida & 0.32 & 0.21 \\
\hline Dinoflagellates & Gyrodinium spirale & 0.35 & -0.22 \\
\hline Ciliates & Distephanus speculum & 0.36 & -0.66 \\
\hline Diatoms & Chaetoceros danicus & 0.37 & -0.15 \\
\hline Diatoms & Stephanopyxis turris & 0.39 & -0.57 \\
\hline Diatoms & Eucampia zodiacus & 0.39 & -0.54 \\
\hline Dinoflagellates & Gyrodinium cf. fusiforme & 0.39 & 0.33 \\
\hline Ciliates & Phaeocystis spp. & 0.40 & 0.21 \\
\hline Dinoflagellates & Dinophysis acuminata & 0.41 & 0.54 \\
\hline Diatoms & Thalassiosira gravida/rotula & 0.41 & -0.40 \\
\hline Diatoms & Chaetoceros decipiens & 0.42 & -0.08 \\
\hline Dinoflagellates & Protoperidinium cf. stenii & 0.42 & 0.33 \\
\hline Diatoms & Lauderia annulata & 0.44 & 0.36 \\
\hline Dinoflagellates & Protoperidinium sp. & 0.44 & 0.25 \\
\hline Dinoflagellates & Warnowia spp. & 0.47 & -0.21 \\
\hline Dinoflagellates & Ceratium furca & 0.48 & -0.05 \\
\hline Diatoms & Chaetoceros concavicornis & 0.50 & -0.20 \\
\hline Dinoflagellates & Small naked dinoflagellates & 0.50 & 0.44 \\
\hline Diatoms & Pseudo-nitzschia spp. & 0.50 & -0.16 \\
\hline Diatoms & Guinardia delicatula & 0.51 & 0.32 \\
\hline Diatoms & Guinardia striata & 0.51 & -0.55 \\
\hline Diatoms & Rhizosolenia shrubsolei & 0.52 & -0.17 \\
\hline Dinoflagellates & Gymnodinium spp. & 0.53 & 0.43 \\
\hline Diatoms & Pleurosigma spp. & 0.55 & -0.42 \\
\hline Diatoms & Thalassionema delicatula & 0.56 & -0.30 \\
\hline Ciliates & Cryptophyceae & 0.58 & 0.32 \\
\hline Diatoms & Leptocylindrus danicus & 0.59 & 0.35 \\
\hline Dinoflagellates & Katodinium cf. glaucum & 0.59 & -0.03 \\
\hline Dinoflagellates & Ceratium fusus & 0.60 & -0.16 \\
\hline Dinoflagellates & Amphidinium cf. sphenoides & 0.62 & 0.04 \\
\hline Diatoms & Detonula pumila & 0.68 & -0.41 \\
\hline Diatoms & Apterionelopsis glacialis & 0.70 & 0.18 \\
\hline Diatoms & Chaetoceros socialis & 0.72 & 0.08 \\
\hline Diatoms & Proboscia alata & 0.74 & -0.33 \\
\hline Diatoms & Nitzschia longissima & 0.78 & -0.20 \\
\hline
\end{tabular}

another assemblage (negative loads) containing the most abundant medium-sized centric diatoms (PC2 was negatively correlated with the logarithm of the total diatom abundance $(\mathrm{r}=-0.2)$ ) that thrived with the upwelling inputs. Thus, the distribution of this component showed the spatial segregation of microplankton assemblages in the water column.

\section{Distribution of Dinophysis acuminata and Myrionecta rubra}

Patches of Dinophysis acuminata $(5 \times$ $10^{3}$ cells l$^{-1}$ ) were found to be moving around the Ría, from 31 May to 10 June, and high densities of this species occupied the whole Ría following the downwelling pulses after 10 June (Fig. 4). Myrionecta rubra also exhibited a patchy distribution, but its maxima did not always coincide with those of $D$. acuminata. Vertical profiles revealed that, except on 31 May, $D$. acuminata maxima were located in the top layer ( 0 to $6 \mathrm{~m}$ ), and those of $M$. rubra coincided with or were very near them ( $<1 \mathrm{~m}$ distance) in 12 of 27 profiles, but were quite separated from $D$. acuminata in the other cases (Table 3 ).

\section{Dinoflagellate assemblages during intensive sampling}

The dinoflagellate community was dominant during the downwelling pulse in the intensive sampling. Three components, which explained $39.1 \%$ of the total variance in the original data set, were extracted by the PCA. The first principal component (PC1) explained $18.9 \%$ of the total variance in the dinoflagellate assemblage, the second (PC2) accounted for $10.7 \%$, and the third (PC3) accounted for $9.4 \%$. Among all the dinoflagellate groups considered, only Dinophysis acuminata had high $(>0.7)$ positive loads with PC1 (Table 4).

The load ordination of PC1 in this analysis, together with the negative correlation of the scores of this component with the logarithm of the total cell abundance $(r=0.7)$, suggests that this component explained the variance due to variations in cell abundance. Consequently, high negative scores indicated the most abundant species during the intensive sampling. Several large dinoflagellates, including Protoperidinium cf. pentagonum and Gonyaulax polygramma, were the species with the highest negative loads with PC2. Positive scores corresponded with Gyrodinium spp., Prorocentrum micans and Myrionecta rubra. Analysis of correlations between each 

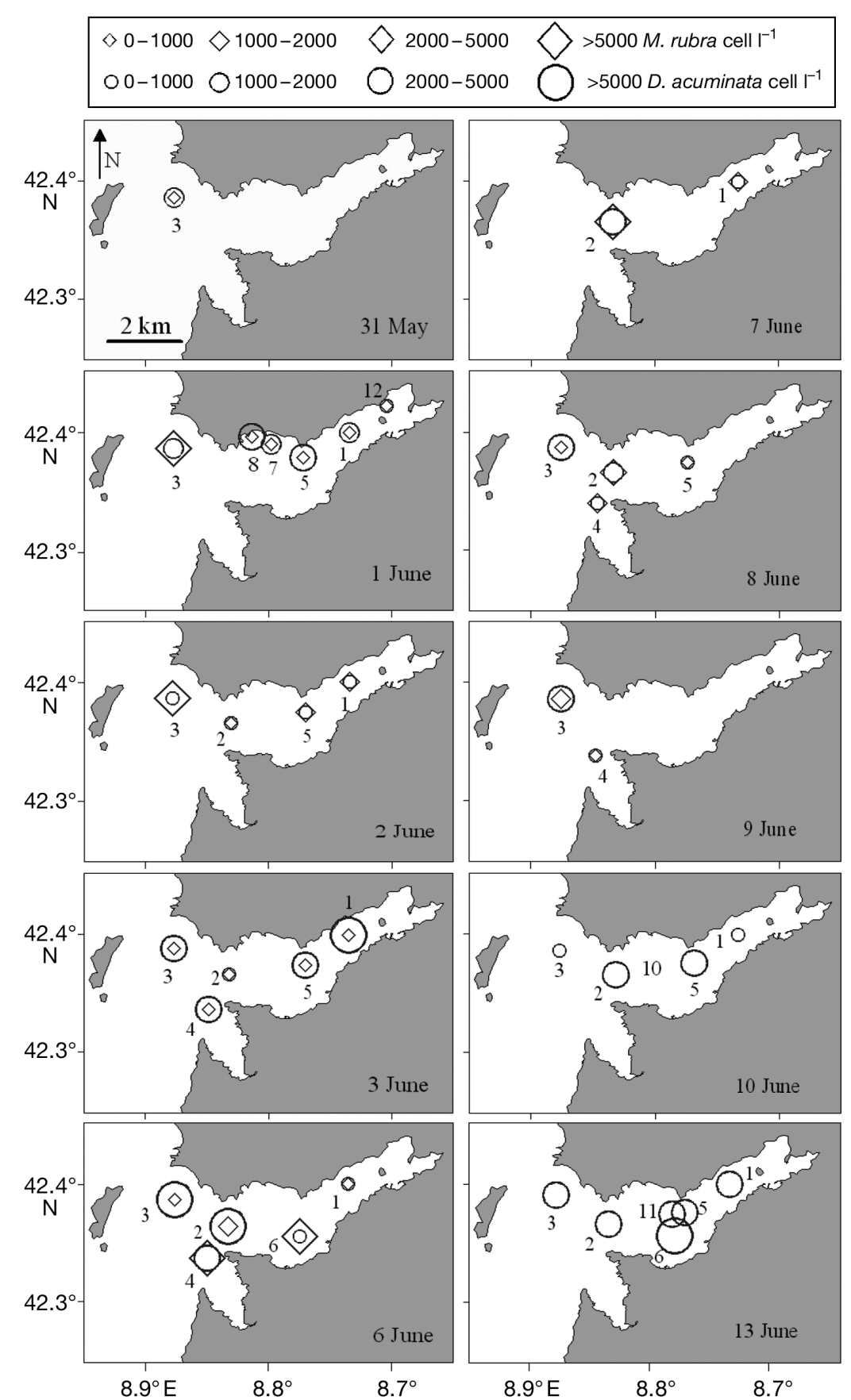

Fig. 4. Dinophysis acuminata and Myrionecta rubra. Horizontal distribution (cell maxima at each station) in Ría de Pontevedra during the survey. No data for M. rubra are available on 10 and 13 June

component and the taxa presented showed that PC2 was higher in samples taken above $10 \mathrm{~m}$, while negative scores of PC2 were associated with samples taken below $12 \mathrm{~m}$. PC3 differentiated an assemblage composed of $P$. micans, Dinophysis acuminata, and $M$. rubra among other species with negative loads $(<-0.40)$. This factor also showed a significant correla- tion with the concentration of each species at 2 to $4 \mathrm{~m}$, suggesting that species showing negative scores for this component were more concentrated at these depths during the sampling period. Interpretations of PC2 and PC3 suggest the presence of a phytoplankton assemblage that was being pushed downwards (below $12 \mathrm{~m}$ ) by downwelled waters (PC2), and another community which persisted in surface waters (above $10 \mathrm{~m} ; \mathrm{PC} 2$ ) and aggregated at 2 to $4 \mathrm{~m}$ by active swimming (PC3).

\section{Vertical distribution of Dinophysis acuminata and Myrionecta rubra during intensive sampling}

The downwelling pulse led to almost complete homogenization of the upper 12 to $15 \mathrm{~m}$ of the water column during the intensive sampling (Fig. 5). Dinophysis acuminata maxima were observed usually around $4 \mathrm{~m}$, but a dense population $\left(2 \times 10^{5}\right.$ to $5 \times 10^{5}$ cells $\left.\mathrm{l}^{-1}\right)$ of this species was concentrated in the top 4 to $8 \mathrm{~m}$ of the water column during the whole period, except for the profile at 20:30 h. Thus, D. acuminata did not perform a clear daily vertical migration, but rather showed changes in aggregation patterns in the warmer surface layer between 0 and $8 \mathrm{~m}$. Myrionecta rubra had a very patchy vertical distribution, i.e. it concentrated between 0 and $2 \mathrm{~m}$, in the profiles of 17:00 and 06:30 h, but was almost homogeneously distributed in the top $8 \mathrm{~m}$ at other times.

\section{In situ specific division rate}

Division of Dinophysis acuminata, which was estimated at the layer of the D. acuminata maximum, was strongly phased during 13-14 June (Fig. 6). The maximum frequency of paired cells $\left(f_{\mathrm{c}}\right)$ occurred between 04:30 and 05:30 h, while the maximum frequency of recently divided cells $\left(f_{\mathrm{r}}\right)$ occurred after sunrise (06:30 - 07:30 h). Sulcal list regeneration was completed by 08:30 $\mathrm{h}$ and no further division was observed after this time. Division time $\left(1 / 2\left(T_{\mathrm{C}}+T_{\mathrm{r}}\right)\right)$ was $2.01 \mathrm{~h}$. The mean daily specific growth, $\mu$, was $0.51 \mathrm{~d}^{-1}$. Maximum observed values of $f_{\mathrm{c}}$ were $<50 \%$ of those of $f_{\mathrm{r}}$. 
Table 3. Depth (m) of cell maxima for Dinophysis acuminata and Myrionecta rubra (italics) at each station during each day of the survey; -: no data. Co-occurrences of cell maxima of the 2 species in the same depth are shaded (M: May, J: June)

\begin{tabular}{|ccccccccccc|}
\hline Stn & $31 \mathrm{M}$ & $1 \mathrm{~J}$ & $2 \mathrm{~J}$ & $3 \mathrm{~J}$ & $6 \mathrm{~J}$ & $7 \mathrm{~J}$ & $8 \mathrm{~J}$ & $9 \mathrm{~J}$ & $10 \mathrm{~J}$ \\
\hline 1 & - & $6.0 ; 0.70$ & $1.2 ; 5.3$ & $3.3 ; 1.0$ & $1.2 ; 1.2$ & $3.8 ; 3.8$ & - & - & 1.3 & 3.0 \\
2 & - & - & $5.4 ; 25$ & $5.4 ; 5.4$ & $3.3 ; 3.3$ & $8.8 ; 0.7$ & $0.8 ; 3.4$ & - & 1.4 & 3.2 \\
3 & $21.0 ; 21.0$ & $5.0 ; 5.0$ & $1.1 ; 1.1$ & $0.9 ; 0.9$ & $1.1 ; 4.5$ & - & $1.0 ; 11.1$ & $2.0 ; 16.4$ & 3.0 & 1.0 \\
4 & - & - & - & $4.5 ; 6.5$ & $5.8 ; 5.8$ & - & $4.4 ; 2.4$ & 2.0 & - & - \\
5 & - & $3.0 ; 11.3$ & $3.4 ; 8.2$ & $0.8 ; 18.6$ & - & - & $8.5 ; 2.0$ & - & 0.7 & 2.3 \\
6 & - & - & - & - & $1.4 ; 4.3$ & - & - & - & - & 4.7 \\
7 & - & $0.6 ; 0.6$ & - & - & - & - & - & - & - \\
8 & - & $1.0 ; 1.0$ & - & - & - & - & - & - & - & - \\
9 & - & - & - & - & - & - & - & - & - \\
10 & - & - & - & - & - & - & - & - & 2.4 & - \\
11 & - & - & - & - & - & - & - & - & - & 3.0 \\
12 & - & $2.0 ; 2.8$ & - & - & - & - & - & - & - & - \\
\hline
\end{tabular}

Table 4. Correlation coefficients of species and taxa selected for principal component analysis (PCA) with the 3 principal components for the dinoflagellate community found during the day-cycle intensive sampling (13-14 June 2005). Species and taxa are ordered according to $\mathrm{PC} 1$. The highest positive loads for PC2 and PC3 are in bold, while the highest negative loads are in bold italic. Target taxa in this study are also in bold text

\begin{tabular}{|lrrr|}
\hline Taxon & PC1 & PC2 & PC3 \\
\hline Protoperidinium cf. steinii & -0.72 & 0.19 & 0.02 \\
Gymnodinium sp. & -0.70 & 0.32 & -0.39 \\
Gyrodinium sp. & -0.67 & $\mathbf{0 . 4 3}$ & -0.23 \\
Protoperidinium depressum & -0.64 & -0.20 & 0.11 \\
Protoperidinium cf. conicum & -0.62 & $\mathbf{- 0 . 5 0}$ & -0.20 \\
Torodinium sp. & -0.57 & 0.20 & 0.12 \\
Cochlodinium sp. & -0.55 & 0.04 & $-\mathbf{0 . 6 0}$ \\
Protoperidinium cf. oceanicum & -0.52 & -0.36 & -0.02 \\
Pyrocystis lunula & -0.47 & -0.13 & 0.29 \\
Ceratium lineatum & -0.47 & 0.08 & $\mathbf{0 . 4 8}$ \\
Dinophysis acuta & -0.41 & 0.00 & $\mathbf{0 . 4 0}$ \\
Myrionecta rubra & -0.39 & $\mathbf{0 . 4 0}$ & $-\mathbf{0 . 5 7}$ \\
Ceratium fusus & -0.38 & -0.05 & 0.25 \\
Ceratium furca & -0.34 & -0.13 & -0.02 \\
Protoperidinium sp. & -0.34 & -0.07 & -0.24 \\
Protoperidinium claudicans & -0.34 & 0.32 & 0.10 \\
Protoperidinium cf. pentagonum & -0.29 & $\mathbf{- 0 . 6 2}$ & -0.19 \\
Gonyaulax polygramma & -0.26 & $\mathbf{- 0 . 5 8}$ & 0.20 \\
Protoperidinium divergens & -0.22 & $\mathbf{- 0 . 4 7}$ & $-\mathbf{0 . 4 6}$ \\
Gonyaulax spinifera & -0.21 & -0.22 & 0.11 \\
Prorocentrum micans & -0.15 & $\mathbf{0 . 4 8}$ & $\mathbf{- 0 . 5 0}$ \\
Dinophysis rotundata & -0.08 & -0.35 & -0.30 \\
Diplopsalis cf. lenticula & -0.07 & -0.04 & 0.18 \\
Protoperidinium leonis & -0.06 & -0.12 & 0.14 \\
Ceratium tripos & 0.14 & $\mathbf{- 0 . 5 3}$ & -0.25 \\
Dinophysis ovum & 0.17 & -0.17 & -0.34 \\
Protoperidinium diabolus & 0.23 & $\mathbf{- 0 . 4 8}$ & -0.26 \\
Dinophysis skagii & 0.44 & 0.32 & -0.22 \\
Dinophysis acuminata & 0.71 & -0.09 & $\mathbf{- 0 . 4 2}$ \\
\hline & & & \\
\hline
\end{tabular}

\section{Characterization of Dinophysis acuminata cells}

Specimens with starch granules, i.e. deeply stained with Lugol's solution, were clearly distinguished from those with no deposits (Fig. 7). These granules were

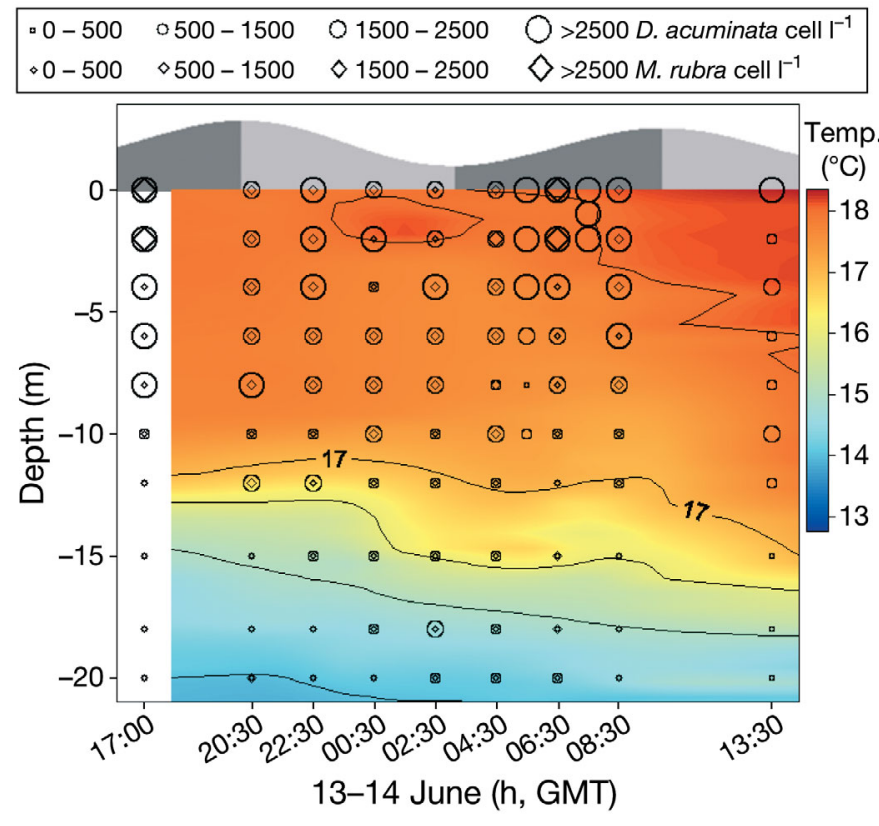

Fig. 5. Dinophysis acuminata and Myrionecta rubra. Vertical distribution and abundance during intensive sampling on 13-14 June at Stn 6. Colour and contour lines: temperature of water column $\left({ }^{\circ} \mathrm{C}\right)$; top horizontal bar: tidal state (dark grey shows increasing tide)

spherical, with an average diameter of $7.55 \pm 1.59 \mu \mathrm{m}$ ( $\mathrm{n}=50$ ), and 2 distinct patterns of distribution: (1) clumped (Fig. 7B), which is the predominant pattern, and (2) in chain-like necklaces (Fig. 7C). The spherical food vacuoles of Dinophysis acuminata, which were $5.66 \pm 1.62 \mu \mathrm{m}$ in size, were semitransparent when observed under bright-field light microscopy, and often occupied most of the cell volume, leading to bulky and much larger specimens (Fig. 7D). Their contents occasionally showed remains of DNA in specimens stained with SYBR-Green (Fig. 7E).

During the first week of the cruise, the frequency of cells with starch deposits increased from $13.6 \%$ on 


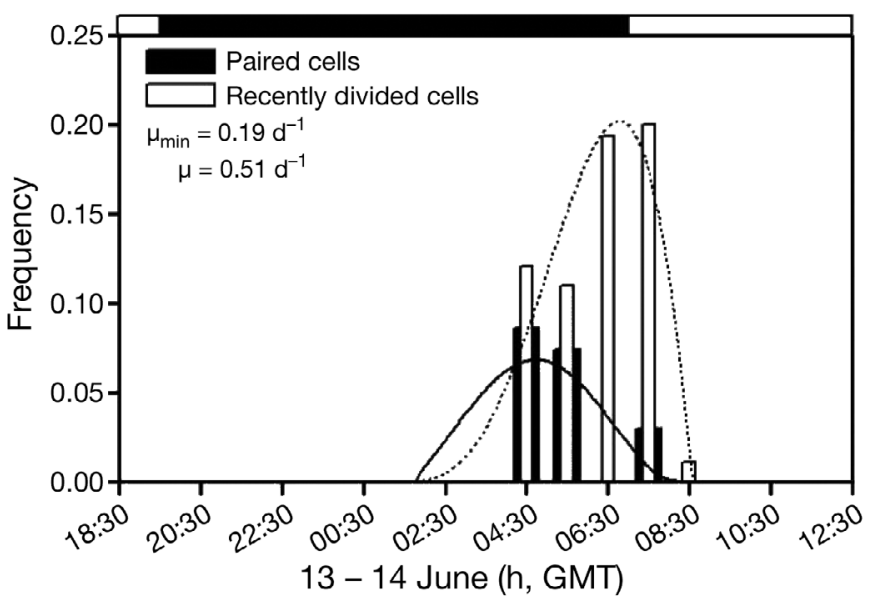

Fig. 6. Dinophysis acuminata. Temporal distribution of the frequency $(\%)$ of paired cells $\left(f_{c}\right)$ and of recently divided cells $\left(f_{\mathrm{r}}\right)$ during intensive sampling on 13-14 June at Stn 6, and their fit to a Gaussian functions ( - and …., respectively). Black bar on top of graph: dark hours

1 June to $24.6 \%$ on 2 June (Fig. 8A). On 3 June, few cells contained starch deposits. Three days later, however, a high proportion of starch containing cells $(54.8 \%)$ was found, and this number again decreased until the end of the cruise, when none of the cells analyzed contained starch deposits. The frequency of Dinophysis acuminata containing food vacuoles was low $(\sim 5 \%)$ during the first days, but increased to $16.3 \%$ from 8 June onwards. This increment coincided with the rise in cell numbers at the beginning of downwelling conditions.

Selected profiles of the vertical distribution of the percentage of cells with starch deposits are shown in Fig. 8, where only days with maximum percentages of starch deposits (2, 6 and 8 June) are represented. Frequencies of cells with starch granules were higher in the top layer ( 0 to $5 \mathrm{~m}$ ), where light availability was 50 to $100 \%$ of incident radiation, but some were eventually found in deeper waters (14 to $28 \mathrm{~m}$ ), where light availability was below $2 \%\left(\sim 16.45 \mu \mathrm{mol}\right.$ photons $\left.\mathrm{m}^{-2} \mathrm{~s}^{-1}\right)$ and $0.07 \%$ $\left(0.68 \mu \mathrm{mol}\right.$ photons $\left.\mathrm{m}^{-2} \mathrm{~s}^{-1}\right)$ of incident light, respectively.
Maximum frequencies of vacuolated cells were found at $4.4 \mathrm{~m}$ on 8 June $(82 \%)$ and at $1.0 \mathrm{~m}$ on 9 June $(56 \%)$. At the beginning of the cruise ( 2 June), however, the distribution in the water column was more homogeneous, and percentages of up to $12 \%$ vacuolated cells could be found even at $16.5 \mathrm{~m}$. High Myrionecta rubra

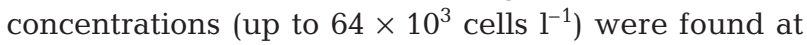
$16 \mathrm{~m}$ on 9 June, while the highest concentration (640 cells $\mathrm{l}^{-1}$ ) was found at $1 \mathrm{~m}$ on 2 June. Therefore, the vertical distribution of the predator and its potential prey was quite distinct in some profiles at Stn 3.

Horizontal and vertical profiles were all taken at the same time period of the day, i.e. between 10:00 and 11:40 h GMT, except for one profile that was taken on 9 June (7:20 h GMT).

Changes in cell volume during the cruise were statistically significant $(\mathrm{p}<0.05$, Tukey's and Bonferroni's tests, $\mathrm{n}=60$ ) at both stations, and were quite evident in in vivo observations on board (Table 5). Cells were significantly larger at the end of the cruise than at the beginning (during upwelling conditions), with a percentage increase in biovolume of $\sim 27 \%$ at both stations.

Throughout the cruise, in vivo observations with the epifluorescence microscope showed that Dinophysis acuminata cells containing reddish-brown chloroplasts fluoresced orange when observed under a longpass (LP) blue filter set (Ex 450/490 nm, Em $520 \mathrm{~nm}$ LP) (Fig. 9A,B,G,H). The intensity of this orange fluorescence was not affected by the presence (Fig. 9G,H) or absence (Fig. 9A,B) of food vacuoles. However, when cells had pale greenish chloroplasts, the autofluorescence was reddish and weak, and faded rapidly (Fig. 9C,D). Measurements of light intensity are not available, but all fluorescence pictures were taken with the same exposure time in an attempt to compare the intensity of fluorescence. When a shortpass filter set specific for phycoerythrin was employed (Ex $546 \mathrm{~nm}$, Em $585 \mathrm{~nm}$ ), differences in colour and autofluorescence intensity were clearly observed (Fig. 9E,F), and cells containing reddish-brown chloroplasts again showed phycoerythrin/orange autofluo-
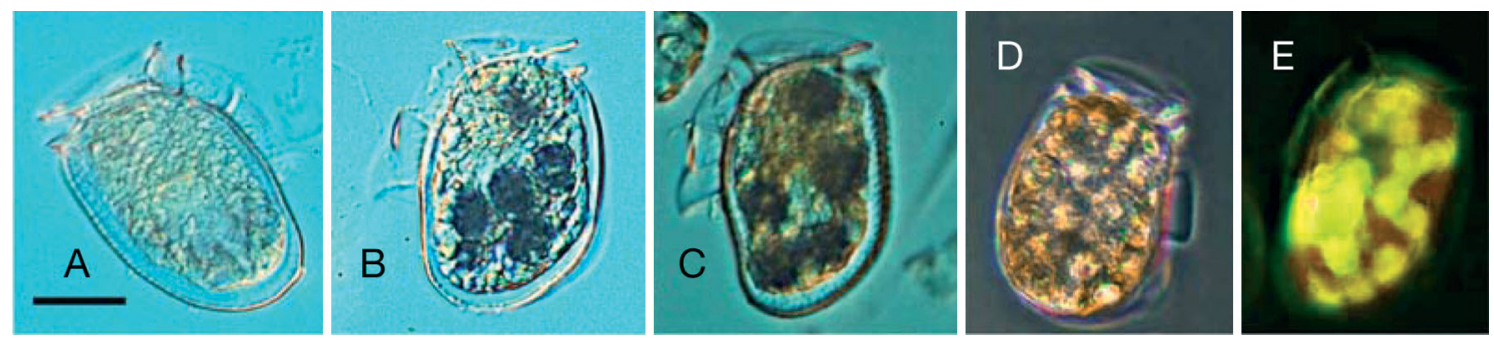

Fig. 7. Dinophysis acuminata. Patterns of starch deposits and vacuolation: (A) starch-free cell, (B) starch deposits in clumps, (C) starch deposits in the form of a chain or necklace, (D) very swollen cell full of digestive vacuoles, and (E) SYBR-Green stained specimen showing food vacuoles with DNA content. Scale bar $=20 \mu \mathrm{m}$ and is the same for all frames 

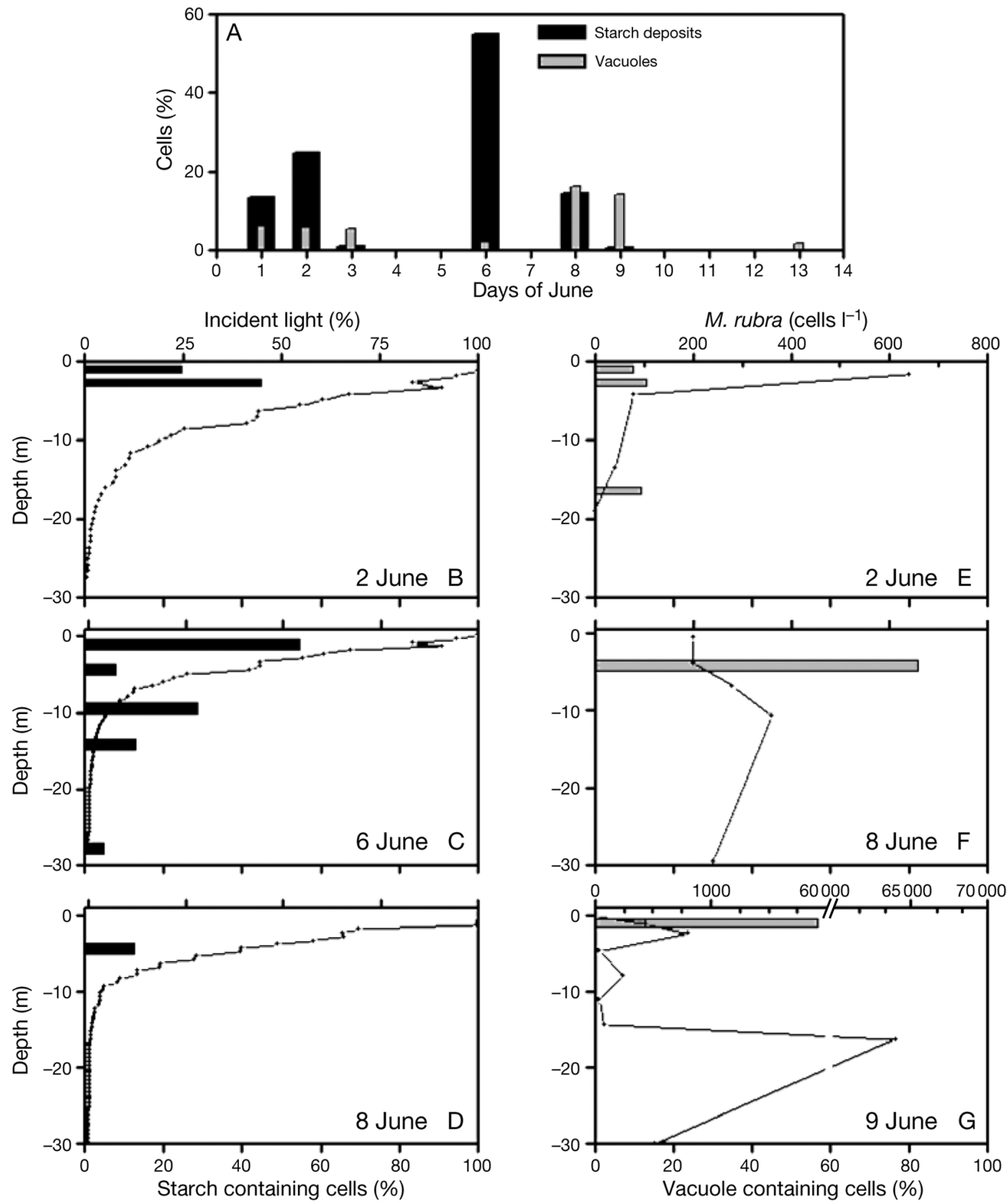

Fig. 8. Dinophysis acuminata and Myrionecta rubra. (A) Temporal variability in the frequency of starch accumulation and vacuolation in cells in the cell maxima at Stn 3. (B-D) Vertical distribution of light intensity and of the frequency of starch containing cells on 2,6 and 8 June at the same station. (E-G) Vertical distribution of M. rubra and of the frequency of cells with digestive vacuoles on 2,8 and 9 June at the same station

rescence, while greenish chloroplasts showed a weak reddish fluorescence.

Some parasitized Dinophysis acuminata cells with green autofluorescence were detected at the end of the cruise (Fig. 9I,J). This autofluorescence was distinct from that of their chloroplasts. The use of the DNA stain SYBRGreen confirmed the presence of mature (Fig. 9K) and young (Fig. 9L) stages of the parasite Amoebophrya sp. 
Table 5. Dinophysis acuminata. Measurements (mean $\left.\pm \mathrm{SD}_{i} \mathrm{n}>60\right)$ of length $(L, \mu \mathrm{m})$, dorso-ventral depth $(W, \mu \mathrm{m})$ and biovolume $\left(\mu \mathrm{m}^{3}\right)$ of cells from samples collected at Stns 1 and 3. J: June

\begin{tabular}{|lcclc|}
\hline Station & Day & $L$ & \multicolumn{1}{c|}{$W$} & Biovolume \\
\hline 1 & 03J & $40.77 \pm 1.95$ & $26.71 \pm 1.97$ & $11614.20 \pm 1864.45$ \\
1 & 13J & $44.94 \pm 2.48$ & $30.34 \pm 21.14$ & $15993.03 \pm 2859.50$ \\
3 & 02J & $40.98 \pm 2.33$ & $25.62 \pm 2.28$ & $11365.14 \pm 2120.03$ \\
3 & 06J & $43.27 \pm 2.27$ & $26.35 \pm 2.29$ & $13012.95 \pm 2245.50$ \\
3 & 13J & $44.25 \pm 2.74$ & $30.16 \pm 2.45$ & $15638.67 \pm 3058.45$ \\
\hline
\end{tabular}

\section{DISCUSSION}

\section{Distribution of Dinophysis acuminata in relation to Myrionecta rubra}

Microplankton assemblages described in this paper are common to those described during late spring (May to June) upwelling-downwelling cycles in the Galician Rías Baixas (Tilstone et al.
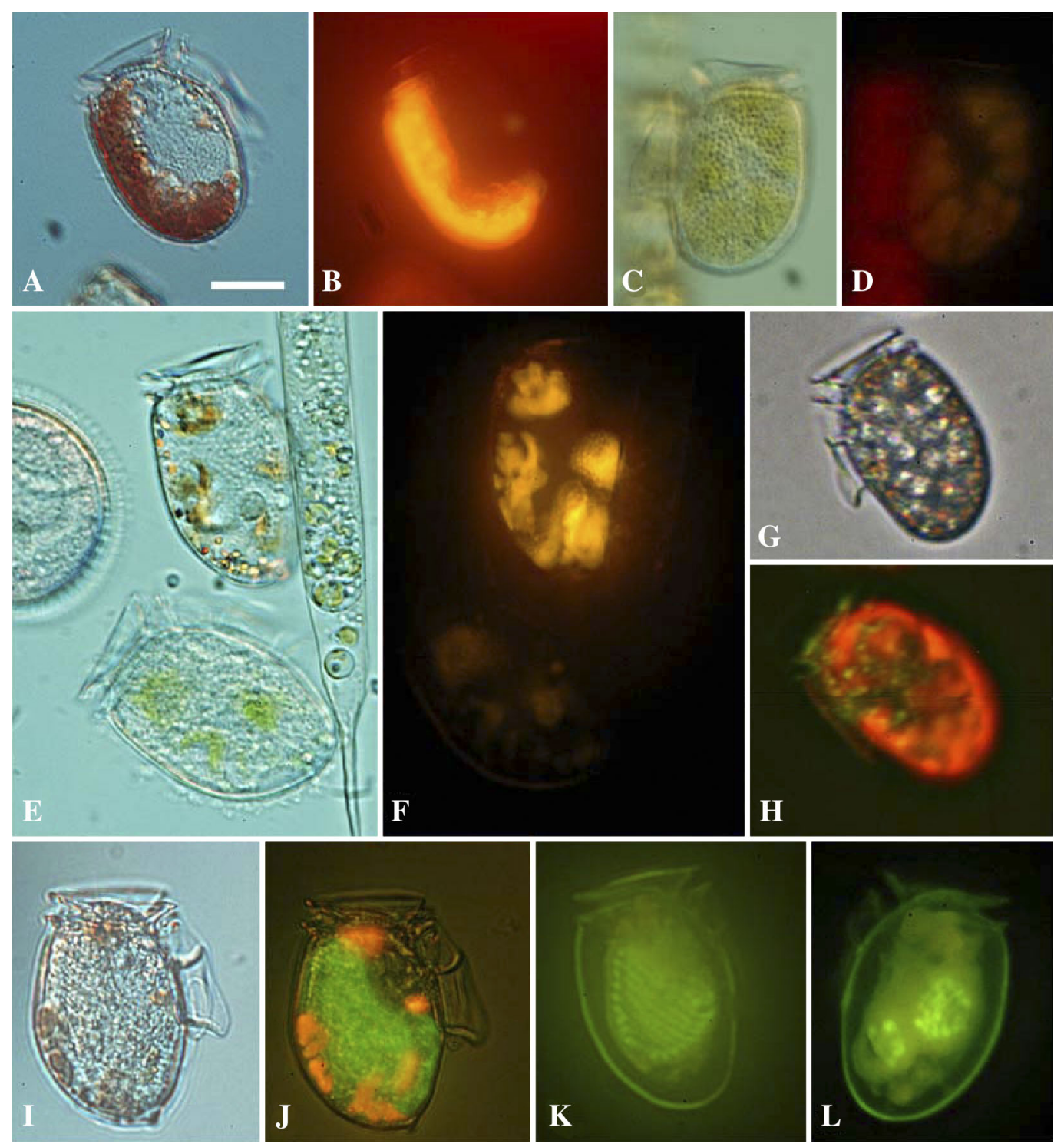

Fig. 9. Dinophysis acuminata. (A) Phase contrast and (B) epifluorescence micrographs of a nonvacuolated cell with peripheral pigmentation. ( $\mathrm{C}, \mathrm{D})$ Phase contrast and epifluorescence micrographs of a greenish, presumably dead specimen. (E) Phase contrast and (F) epifluorescence micrographs comparing the colour and autofluorescence of a greenish nonviable specimen (lower part) surrounded by picoplankton-like particles, and a healthy specimen (upper part). (G) Phase contrast and (H) fluorescent micrographs of a very vacuolated specimen. (I) Bright field and (J) epifluorescence micrographs of a cell infected with an Amoebophrya-like parasite. $(\mathrm{K}, \mathrm{L})$ Epifluorescence micrographs of SYBR-Green-stained cells showing the typical punctuate nuclei of the parasite 
1994, Nogueira \& Figueiras 2005). Nevertheless, special attention is paid here to the distribution, within these assemblages, of the toxin producing Dinophysis acuminata and of its potential prey, the ciliate Myrionecta rubra, in a year when diarrhetic shellfish poisoning (DSP) outbreaks associated with the former began in early March (Instituto Tecnolóxico para o Control do Medio Mariño de Galicia, INTECMAR; www.intecmar.org). Studies in Japanese coastal waters (Nishitani et al. 2005, Koike et al. 2007) have focused on the relationship between Dinophysis populations and potential cryptophyte and other picoplanktonic prey. These studies were conducted before Park et al. (2006) discovered that $D$. acuminata could be grown successfully, with good division rates, if fed with the ciliate $M$. rubra (itself a predator on cryptophytes of the genera Teleaulax and Geminigera). For this reason, the present study focused on the interplay between Dinophysis and its potential ciliate prey $M$. rubra, although Teleaulax-like cryptophytes were also counted and included in the PCA analyses.

Results from the PCA showed that predator and prey co-occurred in the same microplankton assemblage, and that their maxima were usually restricted to the upper layer of water, which is limited during the day by a diurnal thermocline. Prorocentrum micans and Dinophysis acuminata-2 dinoflagellate species that had already bloomed in Ría de Pontevedra the week before the cruise started (Pizarro 2008) — were the dominant species in this layer. Therefore, we can assume this assemblage to be comprised of species that did not profit from the upwelled water inputs, and were mostly flushed out during the upwelling events. Nevertheless, our results showed that $D$. acuminata was not homogeneously dispersed and, even when upwelling was most intense, it was always possible to locate patches of this species in various locations in the Ría.

An intriguing question concerns the mechanism by which Dinophysis acuminata encounters its potential ciliate prey. Myrionecta rubra is an extremely fast swimmer, and it is most unlikely that it can be chased by the dinoflagellate. Our results show that the cell maxima of the 2 organisms were neither at the same station within the Ría (horizontal distribution), nor at the same depth at the same station (vertical distribution) in $>50 \%$ of the observations. If Dinophysis pursued $M$. rubra using some kind of biochemical attractant, this would only be effective at smaller spatial scales than those separating the cell maxima of the 2 species in $\sim 50 \%$ of the cases shown here. The present study suggests that populations of the 2 organisms have distinct responses to physical forcing and their own niches, although both occur in common water masses and occasionally meet, resulting in $M$. rubra being attacked by starved/hungry cells of Dinophysis.

\section{Vertical migration and division rate of Dinophysis acuminata}

Different Dinophysis species have been shown either to exhibit distinct migration patterns in various locations or to remain at the same depth (pycnocline) throughout the daily cycle (reviewed by Maestrini 1998).

Throughout the cruise, Dinophysis acuminata always appeared in the upper layer (0 to $5 \mathrm{~m}$ ) from 06:00 to $16: 00 \mathrm{~h}$ GMT. A similar distribution was observed during the intensive sampling on 13-14 June. These observations are distinct from previous observations in Ría de Vigo (Villarino et al.1995) and Ría de Pontevedra (Reguera et al. 2003), that showed a clearcut migration of the cell maxima of $D$. acuminata, from surface waters at dawn to $\sim 10 \mathrm{~m}$ depth at night. Different migration patterns by the same species in the same location can be attributed to differing responses to different hydrodynamic conditions (reviewed by Maestrini 1998, Velo-Suárez et al. 2009). Nevertheless, the results of Reguera et al. (2003) were obtained at the same time of the year and also under downwelling conditions. We do not have data to determine whether downwelling intensity during Reguera et al's. (2003) study was very different from that described here, which might have caused a different swimming response in $D$. acuminata. However, an alternative possibility is that migratory behaviour in D. acuminata is determined by intrinsic factors, such as the nutritional status of the cells and/or the phase of population growth. This species may be able to switch from migratory to layer-forming behaviour depending on its nutritional status.

Another surprising result of this study concerns the division rate observed in the Dinophysis acuminata population during the downwelling event. It has been often assumed that increased numbers in Dinophysis populations are associated with the onset of thermohaline gradients and water column stability. However, the estimated value of $\mu\left(0.51 \mathrm{~d}^{-1}\right)$ in this cruise was almost within the range of values $\left(0.6\right.$ to $\left.0.9 \mathrm{~d}^{-1}\right)$ observed in cultures of $D$. acuminata, D. fortii and $D$. caudata with a good supply of Myrionecta rubra (Park et al. 2006, 2008, Nagai et al. 2008, Nishitani et al. 2008). Unfortunately, we were unable to obtain good estimates of division rates during other days of the cruise, since daily sampling times did not coincide with the time window when phased division of D. acuminata takes place; however, one isolated observation from a vertical net haul in Stn 2 (Fig. 1) on 9 June at $05: 30$ h showed that $15 \%$ of $D$. acuminata cells were undergoing division. This value is comparable to that observed at the same time of day during the intensive sampling at Stn 6 on 13-14 June. 


\section{Characterization of Dinophysis acuminata cells}

Dinophysis acuminata, which was present throughout the whole cruise, revealed large spatio-temporal variability with respect to the accumulation of starch granules, heterotrophic behaviour (reflected in cell vacuolation), and size. The analysis of the vertical distribution of starch containing cells in this cruise showed that cells tended to accumulate starch mostly in the photic layer, where light availability was high, supporting the hypothesis that accumulation of starch indicates photosynthetic activity. However, the physiological significance of this accumulation in Dinophysis spp., and especially the causes of its variability, are difficult to interpret. In laboratory cultures of D. caudata fed with Myrionecta rubra, experiments testing plastid survival in starved cells showed that starch accumulation was highest $7 \mathrm{~d}$ after starvation (and higher than in well-fed cells), and declined rapidly thereafter (Park et al. 2008). Remains of starch granules could be observed up to $56 \mathrm{~d}$ after starvation. These results suggest that, at least in the case of D. caudata cultures, starch seems to play the role of a storage product between consecutive feedings, and the lack of starch would indicate a long period ( $>8 \mathrm{wk}$ ) of prey limitation

Digestive vacuoles are the unequivocal sign of recent heterotrophic feeding, and their presence in Dinophysis spp. cells immediately after feeding on Myrionecta rubra has been proven in culture experiments (Park et al. 2006, Nishitani et al. 2008). Results from this study indicate that prey accessibility to Dinophysis was quite variable, both horizontally and vertically. These results are in agreement with previous observations on the variability in frequency of vacuolated cells of Dinophysis in Maine waters (USA) and in the Baltic Sea (Jacobson \& Andersen 1994, Carvalho et al. 2008). Assuming that $M$. rubra constitutes the main food of $D$. acuminata in the Galician Rías, the matchmismatch of their respective distributions might account for the variations in cell vacuolation. It is important to note that in experiments with D. caudata, photosynthetic capabilities can persist after 2 mo of starvation (Park et al. 2008). Therefore, the co-occurrence of $M$. rubra is not essential for the persistence of D. acuminata populations.

Changes in the size of Dinophysis acuminata during this cruise were clearly related with feeding. At the beginning of the cruise, many cells were slender, with little cellular content; the increment in size coincided with the increased frequency of vacuolation on 8 June. Reguera \& González-Gil (2001) showed that small-cell formation and other transitions in the Dinophysis life cycle are responsible for dramatic changes in the size composition and shape of cells comprising the population. Here, it is shown that heterotrophic feeding in mixotrophic Dinophysis acuminata favours cell enlargement in populations that undergo periods of deprivation.

Acknowledgements. We thank the crew of RV 'Mytilus' for their help and M. M. Daniélou for technical assistance. This work was funded by the EU HABIT project (EC 6FP, GOCECT-2005-003932) and the Spanish TURDIRRIAS project (CTM2006-13884-CO2-02/MAR). This is a contribution to the GEOHAB Core Research Project HABs and Stratification in Upwelling Systems.

\section{LITERATURE CITED}

Álvarez-Salgado XA, Figueiras FG, Pérez FF, Groom S and others (2003) The Portugal coastal counter current off NW Spain: new insights on its biogeochemical variability. Prog Oceanogr 56:281-321

Carpenter EJ, Chang J (1988) Species specific phytoplankton growth rates via diel DNA synthesis cycles. I. Concept of the method. Mar Ecol Prog Ser 43:105-111

> Carpenter EJ, Janson S, Boje R, Pollehne F, Chang J (1995) The dinoflagellate Dinophysis norvergica: biological and ecological observations in the Baltic Sea. Eur J Phycol 30:1-9

Carvalho WF, Minnhagen S, Granéli E (2008) Dinophysis norvergica, more a predator than a producer? Harmful Algae 7:174-183

Cullen JJ, McIntyre JC (1998) Behavior, physiology and the niche of depth-regulating phytoplankton. In: Anderson DM, Cembella AD, Hallegraeff GM (eds) Physiological ecology of harmful algal blooms. NATO ASI, Series G Ecological Sciences 41. Springer, Berlin, p 559-580

Escalera L, Reguera B, Pazos Y, Moroño A, Cabanas JM (2006) Are different species of Dinophysis selected by climatological conditions? Afr J Mar Sci 28:283-288

> Figueiras FG, Jones KJ, Mosquera AM, Álvarez-Salgado XA, Edwards A, McDougall N (1994) Red tide assemblage formation in an estuarine upwelling ecosystem: Ría de Vigo. J Plankton Res 16:857-878

> Fraga S, Anderson DM, Bravo I, Reguera B, Steidinger KA, Yentsch CM (1988) Influence of upwelling relaxation on dinoflagellates and shellfish toxicity in Ría de Vigo, Spain. Estuar Coast Shelf Sci 27:349-361

Franco M (2006) La mitilicultura en Galicia: una actividad de éxito y con futuro. Revista Galega de Economía 15:1-6

Fritz L, Stringher CG, Colepicolo P (1996) Immunolocalisation of nitrate reductase in the marine dinoflagellate Gonyaulax polyedra (Pyrrophyta). J Phycol 32:632-637

> Gentien P, Lunven M, Lehaître M, Dunvent JL (1995) In situ depth profiling of particles sizes. Deep-Sea Res I 42: $1297-1312$

Jacobson DM, Andersen RA (1994) The discovery of mixotrophy in photosynthetic species of Dinophysis (dinophyceae): light and electron microscopical observations of food vacuoles in Dinophysis acuminata, D. norvergica and two heterotrophic dinophysoid dinoflagellates. Phycologia 33:97-110

> Koike K, Nishiyama A, Takishita K, Kobiyama A, Ogata T (2007) Appearance of Dinophysis fortii following blooms of certain cryptophyte species. Mar Ecol Prog Ser 337: 303-309

Lawrence JE, Cembella A (1999) An immunolabeling technique for the detection of diarrhetic shellfish toxins in individual dinoflagellate cells. Phycologia 38:60-65 
MacKenzie L (1992) Does Dinophysis (Dinophyceae) have a sexual lifecycle? J Phycol 28:399-406

Maestrini SY (1998) Bloom dynamics and ecophysiology of Dinophysis spp. In: Anderson DM, Cembella AD, Hallegraeff GM (eds) Physiological ecology of harmful algae blooms. NATO ASI, Series G Ecological Sciences 41 . Springer, Berlin, p 243-266

Marie D, Simon N, Vaulot D (2005) Phytoplankton cell counting by flow cytometry. In: Andersen RA (ed) Algal culturing techniques. Elsevier, London, p $253-269$

Nagai S, Nishitani G, Tomaru Y, Sakiyama S, Kamiyama T (2008) Predation by the toxic dinoflagellate Dinophysis fortii on the ciliate Myrionecta rubra and observation of the sequestration of ciliate chloroplast. J Phycol 44: 909-922

> Nishitani G, Yamaguchi M, Ishikawa A, Yanagiya S, Mitsuya T, Imai I (2005) Relationships between occurrences of toxic Dinophysis species (dinophyceae) and small phytoplankton in Japanese coastal waters. Harmful Algae 4:755-762

Nishitani G, Nagai S, Sakiyama S, Kamiyama T (2008) Successful cultivation of the toxic dinoflagellate Dinophysis caudata (Dinophyceae). Plankton Benthos Res 3:78-85

- Nogueira E, Figueiras FG (2005) The microplankton succession in the Ría de Vigo revisited: species assemblages and the role of the weather-induced, hydrodynamic variability. J Mar Syst 54:139-155

Olenina I, Hajdu S, Elder L, Andersson A and others (2006) Biovolumes and size-classes of phytoplankton in the Baltic Sea. HELCOM Balt Sea Environ Proc No 106, available at www.helcom.fi/stc/files/publications/Proceedings/ bsep106.pdf

Park MG, Kim S, Kim HS, Myung G, Kang YG, Yih W (2006) First succesful culture of the marine dinoflagellate Dinophysis acuminata in cultures. Aquat Microb Ecol 45:101-106

Park MG, Park JS, Kim M, Yih W (2008) Plastid dynamics during survival of Dinophysis caudata without its ciliate prey. J Phycol 44:1154-1163

Pitcher G, Moita T, Trainer V, Kudela R, Figueiras FG, Probyn $T$ (eds) (2005) Global ecology and oceanography of harmful algal blooms, GEOHAB, core research project: HABs in upwelling systems. IOC and SCOR, Paris and Baltimore, MD, p 82

Pizarro GM (2008) Estudio, mediante LC-MS, de la variabilidad del perfil y contenido de toxinas, en poblaciones de Dinophysis spp. agentes de episodios DSP en las Rías Baixas Gallegas. PhD dissertation, University of Vigo

Pizarro G, Escalera L, González-Gil S, Franco JM, Reguera B (2008) Growth, behavior and cell toxin quota of Dinophysis acuta during a daily cycle. Mar Ecol Prog Ser 353: 89-105

Reguera B, González-Gil S (2001) Small cells and intermediate cell formation in species of Dinophysis (Dinophyceae, Dinophysiales). J Phycol 37:318-338
Reguera B, Pizarro G (2008) Planktonic dinoflagellates which produce polyether toxins of the old 'DSP Complex'. In: Botana L (ed) Seafood and freshwater toxins: pharmacology, physiology and detection. CRC Press, Taylor \& Francis, London, p 257-284

Reguera B, Bravo I, Marcaillou C, Masselin P, Fernández ML, Míguez A (1993) Monitoring of Dinophysis spp. and vertical distribution of okadaic acid on mussel rafts in Ria de Pontevedra (NW Spain). In: Smayda T, Shimizu Y (eds) Toxic phytoplankton blooms in the sea. Elsevier, Amsterdam, p 553-558

Reguera B, Bravo I, Fraga S (1995) Autoecology and some life history stages of Dinophysis acuta Ehrenberg. J Plankton Res 17:999-1015

- Reguera B, Garcés E, Bravo I, Pazos Y, Ramilo I, González-Gil S (2003) Cell cycle patterns and estimates of in situ division rates of dinoflagellates of the genus Dinophysis by a postmitotic index. Mar Ecol Prog Ser 249:117-131

> Samuelsson G, Matlick HA, Prezelin BB (1983) Changes in photosystem II account for the circadian rhythm in photosynthesis in Gonyaulax polyedra. Plant Physiol 73: 329-331

Seo KS, Fritz L (2002) Diel changes in pyrenoid and starch reserves in dinoflagellates. Phycologia 41:22-48

Sordo I, Barton ED, Cotos JM, Pazos Y (2001) An inshore poleward current in the NW of the Iberian Peninsula detected from satellite images, and its relation with G. catenatum and $D$. acuminata blooms in the Galician Rias. Estuar Coast Shelf Sci 53:787-799

> Tilstone GH, Figueiras FG, Fraga F (1994) Upwelling-downwelling sequences in the generation of red tides in a coastal upwelling system. Mar Ecol Prog Ser 112:241-253

Utermöhl H (1931) Neue wege in der quantitativen Erfassung des Planktons (mit besonderer Berücksichtigung des Ultraplanktons). Verh Int Ver Theor Angew Limnol 5: 567-596

Velo-Suárez L, González-Gil S, Gentien P, Lunven M and others (2008) Thin layers of Pseudo-nitzschia spp. and the fate of Dinophysis acuminata during an upwelling-downwelling cycle in a Galician Ría. Limnol Oceanogr 53: 1816-1834

> Velo-Suárez L, Reguera B, Garcés E, Wyatt T (2009) Vertical distribution of division rates in coastal dinoflagellate Dinophysis spp. populations: implications for modelling. Mar Ecol Prog Ser 385:87-95

Villarino ML, Figueiras FG, Jones KJ, Álvarez-Salgado XA, Richard J, Edwards A (1995) Evidence of in situ diel vertical migration of a red-tide microplankton species in Ría de Vigo (NW Spain). Mar Biol 123:607-617

Wooster WS, Bakun A, McClain DR (1976) The seasonal upwelling cycle along the eastern boundary of the north Atlantic. J Mar Res 34:131-141

Submitted: May 11, 2009; Accepted: September 4, 2009 Proofs received from author(s): January 22, 2010
Editorial responsibility: Patricia Glibert, Cambridge, Maryland, USA 